\title{
Pengaruh Infeksi Laten Toksoplasmosis Terhadap Lama Rawatan Skizofrenia Episode Pertama
}

\author{
Rina Amtarina ${ }^{1 *}$, Andriza $^{1}$, Nurfi Pratiwi ${ }^{2}$, Sarah Udayana ${ }^{3}$
}

\begin{abstract}
Toxoplasma metabolism effect can rise the dopamine production which aggravate the simptoms of schizophrenia. Some of the research reports that patients which diagnosed with schizophrenia with positive IgG Toxoplasma need longer duration of treatment and may relapse. This study was conducted by cross sectional method on 51 patients with first episode schizophrenia, including acute and temporary psychotic disorder, in Tampan Mental Hospital - Pekanbaru. IgG anti-toxoplasma were detected on the patients at the first treatment in 2019, and then the length period of treatment and the recurrence frequency were monitored in the first year of the course of the disease. From the chi square test result, we can conclude that there's no effect of IgG Toxoplasma on the duration of treatment on the first episode schizophrenia patients as well as the recurrence frequency which monitored in the first year course of the disease $(p>0.05)$. There's no effect of IgG Toxoplasma on the duration of treatment on the first episode schizophrenia patients as well as the recurrence frequency.
\end{abstract}

Keywords: Psychotic, Schizophrenia, Toxoplasma gondii, Toxoplasmosis

Infeksi laten Toxoplasma gondii ( T. gondii) dapat mempengaruhi perjalanan penyakit skizofrenia. Parasit ini dorman membentuk kista di jaringan saraf. Parasit ini kemudian melepaskan toksin yang mengganggu sel neuron, sel glial dan astrosit. Dampak dari metabolisme Toxoplasma ini mengakibatkan produksi dopamin yang berlebihan. ${ }^{1}$ Dampak neuromodulatori ini juga mengakibatkan inhibisi glutamatergik dan nikotinergik. Hal ini dapat memperberat gejala skizofrenia.

Skizofrenia merupakan gangguan psikotik yang dapat berlangsung kronik dan berat. Gejala Skizofrenia dapat timbul mulai usia muda. Onset awal gejala skizofrenia pada laki-laki, sering muncul pada usia 15-25 tahun. Onset awal gejala skizofrenia pada perempuan, sering muncul pada usia lebih tua yaitu antara 25-35 tahun..$^{2-4}$ Parasit

\footnotetext{
* Corresponding author: amtarina@gmail.com

1 KJFD Ilmu Kedokteran Jiwa Fakultas Kedokteran Universitas Riau, Pekanbaru, Riau, Indonesia

2 KJFD Histologi Fakultas Kedokteran Universitas Riau, Pekanbaru, Riau, Indonesia

3 Program Studi Kedokteran Fakultas Kedokteran Universitas Riau, Pekanbaru, Riau, Indonesia
}

T. gondii telah dilaporkan berulang kali memiliki pengaruh terhadap timbulnya skizofrenia. ${ }^{1}$ T. gondii dipertimbangkan dapat memicu gejala psikotik pada orang yang sudah memiliki kerentanan secara genetik dan atau juga dapat memodulasi perjalanan penyakit tersebut. ${ }^{5,6}$

Toxoplasma gondii merupakan parasit obligat interselular yang menyebabkan infeksi toksoplasmosis pada manusia. Seroprevalensi toksoplasmosis berbeda-beda di tiap negara. Menurut penelitian sebelumnya, penyakit ini melanda 6,7\% warga di Korea, $12,3 \%$ di Cina, $23,9 \%$ di Nigeria, $46 \%$ di Tanzania hingga $98 \%$ di beberapa daerah Afrika. Prevalensi toksoplasmosis di Indonesia sendiri telah dilaporkan antara 43 hingga $88 \%$ pada beberapa provinsi. ${ }^{7}$

Pada individu yang imunokompeten, Toxoplasma menyebabkan infeksi laten seumur hidupnya. Parasit bersifat dorman dalam bentuk kista jaringan di saraf dan jaringan otot. Banyak teori yang bertujuan untuk menerangkan mekanisme patogenesis infeksi Toxoplasma di otak. Ada yang melalui jalur pelepasan toksin secara selektif yang 
mengganggu pada sel neuron, sel glial dan astrosit. Dapat juga melalui dampak neuromodulatori dari metabolisme Toxoplasma berupa produksi dopamin yang berlebihan. Mekanisme lain melalui jalur produksi sitokin proinflamasi yang berlebihan dan berkelanjutan yang akhirnya mempengaruhi neuromodulasi. Efek ini mengakibatkan inhibisi berlebihan terhadap neurotransmisi glutamatergik dan nikotinergik. ${ }^{1}$

Parasit yang terdeposit di sistem saraf pusat dapat mempengaruhi sintesis neurotransmiter terutama dopamin. Neurotransmiter lain yang juga dapat dipengaruhi adalah glutamat. Perubahan pada kadar neurotransmiter tersebut dapat menimbulkan gangguan perilaku, perubahan kepribadian dan gangguan psikotik berat seperti skizofrenia. Gejala-gejala halusinasi dan waham yang khas pada skizofrenia disebabkan karena ketidakstabilan dopamin di otak. Gejala gangguan kognitif yang juga terdapat pada pasien skizofrenia disebabkan karena ketidakstabilan glutamat dalam otak. Beberapa penelitian juga menyebutkan bahwa adanya hubungan antara Toxoplasma gondii dengan meningkatnya insiden terjadinya skizofrenia. Pada kepustakaan juga disebutkan adanya peranan Toxoplasma gondii sebagai etiologi dari skizofrenia. ${ }^{8,9}$

Pada penelitian lebih lanjut diketahui bahwa infeksi laten toksoplasmosis dapat menurunkan densitas grey matter pada penderita Skizofrenia. ${ }^{10}$ Penelitian lain dilaporkan juga bahwa skizofrenia yang terinfeksi toksoplasmosis dirawat lebih lama dibanding yang tidak terinfeksi. Mereka juga membutuhkan dosis pengobatan yang lebih besar. ${ }^{1}$ Meskipun demikian, peran $T$. gondii terhadap patofisiologi terjadinya skizofrenia masih banyak pertanyaan. ${ }^{10}$ Penelitian ini bertujuan untuk mengamati dampak toksoplasmosis terhadap lama rawatan pasien skizofrenia yang dirawat di Rumah Sakit Jiwa (RSJ) Tampan Kota Pekanbaru.

\section{METODE}

Penelitian ini merupakan penelitian analitik cross sectional terhadap 51 pasien skizofrenia episode pertama yang dirawat periode tahun 2019 di RSJ Tampan Kota Pekanbaru. Besar sampel minimum diperoleh dengan rumus hitung sampel penelitian untuk penelitian analitik cross sectional. ${ }^{8}$ Adapun kriteria inklusi adalah pasien skizofrenia episode pertama termasuk gangguan psikotik akut dan sementara dan usia 18-60 tahun. Kriteria eksklusi adalah yang memiliki toksoplasmosis akut, gangguan neurologis berat serta gangguan psikiatri lain. Pada pasien tersebut dilakukan deteksi IgG anti Toxoplasma pada rawatan episode pertama tahun 2019. Pada pasien tersebut kemudian diamati perjalanan penyakitnya selama setahun (hingga tahun 2020). Variabel penelitian yang diamati adalah frekuensi rawat inap dalam setahun pertama perjalanan penyakit, dan durasi rawat inap episode pertama. Dilakukan uji analitik terhadap sampel yang terkumpul. Uji analitik yang digunakan adalah uji chi square, hasil dikatakan ada pengaruhnya jika nilai $\mathrm{p}<0,05$.

\section{HASIL}

Berdasarkan durasi rawat inap, didapatkan sebanyak $42,9 \%$ pasien skizofrenia dengan IgG anti Toxoplasma positif mengalami rawat inap kurang atau sama dengan 30 hari pada episode pertama kali. Selebihnya sebanyak $57,1 \%$ pasien yang mengalami rawat inap kurang atau sama dengan 30 hari pada episode pertama kali memiliki IgG anti Toxoplasma negatif. Pada 37 pasien skizofrenia yang mengalami rawat inap lebih dari 30 hari pada episode pertama kali, didapatkan sebanyak 64,9\% pasien skizofrenia dengan IgG anti Toxoplasma positif dan selebihnya sebanyak 35,1\% dengan IgG anti Toxoplasma negatif. Berdasarkan hasil analisis statistik, tidak didapatkan pengaruh IgG anti Toxoplasma terhadap durasi rawat inap skizofrenia episode pertama (nilai $\mathrm{p}>0,05$ ). 
Tabel 1. Pengaruh IgG anti Toxoplasma terhadap durasi rawatan inap

\begin{tabular}{lccccc}
\hline \multirow{2}{*}{ Variabel } & \multicolumn{2}{c}{ IgG Toxoplasma $(+)$} & \multicolumn{2}{c}{ IgG Toxoplasma $(-)$} & Nilai p \\
\cline { 2 - 5 } & $\begin{array}{c}\text { Jumlah } \\
(\mathbf{n = 3 0 )}\end{array}$ & $\begin{array}{c}\text { Persentase } \\
(\%)\end{array}$ & $\begin{array}{c}\text { Jumlah } \\
(\mathbf{n}=\mathbf{2 1})\end{array}$ & $\begin{array}{c}\text { Persentase } \\
(\mathbf{\%})\end{array}$ & \\
\hline $\begin{array}{l}\text { Durasi rawat inap episode pertama } \\
\text { (hari) }\end{array}$ & & & & & \\
$\leq 30$ & 6 & 42,9 & 8 & 57,1 & 0,15 \\
$>30$ & 24 & 64,9 & 13 & 35,1 & \\
\hline
\end{tabular}

Berdasarkan frekuensi rawat inap berulang, didapatkan sebanyak $67,6 \%$ pasien skizofrenia dengan IgG anti Toxoplasma positif menjalani hanya satu kali rawat inap selama setahun pertama perjalanan penyakitnya. Selebihnya sebanyak $32,4 \%$ pasien yang menjalani hanya satu kali rawat inap selama setahun pertama perjalanan penyakitnya memiliki IgG anti Toxoplasma negatif. Pada 14 pasien skizofrenia yang menjalani rawat inap lebih dari satu kali selama setahun pertama perjalanan penyakitnya, didapatkan sebanyak $35,7 \%$ pasien skizofrenia dengan $\mathrm{IgG}$ anti Toxoplasma positif dan selebihnya sebanyak 64,3\% dengan IgG anti Toxoplasma negatif. Berdasarkan hasil analisis statistik, tidak didapatkan pengaruh IgG anti Toxoplasma terhadap frekuensi rawat inap berulang skizofrenia selama setahun pertama perjalanan penyakitnya (nilai $\mathrm{p}>0,05$ ).

Tabel 2. Pengaruh IgG anti Toxoplasma terhadap frekuensi rawat inap berulang

\begin{tabular}{|c|c|c|c|c|c|}
\hline \multirow[b]{2}{*}{ Variabel } & \multicolumn{2}{|c|}{ IgG Toxoplasma (+) } & \multicolumn{2}{|c|}{ IgG Toxoplasma (-) } & \multirow[b]{2}{*}{ Nilai $p$} \\
\hline & $\begin{array}{l}\text { Jumlah } \\
(\mathbf{n}=\mathbf{3 0})\end{array}$ & $\begin{array}{c}\text { Persentase } \\
(\%)\end{array}$ & $\begin{array}{l}\text { Jumlah } \\
(\mathbf{n}=\mathbf{2 1})\end{array}$ & $\begin{array}{c}\text { Persentase } \\
(\%)\end{array}$ & \\
\hline \multicolumn{6}{|c|}{ Frekuensi rawat inap berulang (kali) } \\
\hline $\begin{array}{l}1 \text { kali } \\
>1 \text { kali }\end{array}$ & $\begin{array}{l}25 \\
5\end{array}$ & $\begin{array}{r}67,6 \\
35,7\end{array}$ & $\begin{array}{r}12 \\
9\end{array}$ & $\begin{array}{l}32,4 \\
64,3\end{array}$ & 0,08 \\
\hline
\end{tabular}

\section{PEMBAHASAN}

Pada penelitian ini tidak didapatkan pengaruh atau hubungan IgG Toxoplasma dengan durasi rawat inap episode pertama maupun frekuensi rawat inap berulang pada setahun pertama perjalanan penyakitnya. Hal ini senada dengan penelitian lain yang juga tidak menemukan adanya hubungan durasi lama rawatan sakit skizofrenia dengan infeksi toksoplasmosis. ${ }^{11,12}$

Berbeda dengan sebuah penelitian lain, menunjukkan pasien skizofrenia yang terinfeksi toksoplasmosis memiliki kemungkinan lima belas kali lebih tinggi mengalami perjalanan penyakit yang berkelanjutan. Adanya gambaran perubahan morfologi otak yaitu penurunan densitas grey matter bilateral pada daerah caudatum, median cingulata, talamus dan korteks oksipital serta hemisfer serebelar kiri tampak terlihat hanya pada pasien skizofrenia yang terinfeksi Toxoplasma. Pasien-pasien tersebut juga cenderung mengalami rawatan inap yang lebih lama. ${ }^{13-16}$

Perbedaan hasil penelitian ini dapat saja terjadi karena dipengaruhi berbagai faktor. Durasi rawat inap dan frekuensi rawat inap berulang dapat dipengaruhi dari jenis dan efektivitas obat, kepatuhan minum obat, kepatuhan kontrol rutin dan juga kerentanan genetik. Pada pasien-pasien yang menjadi sampel penelitian ini, mendapat terapi antipsikotik yang berbeda-beda. Sampel juga mendapat jumlah kombinasi dan jenis antipsikotik yang beragam. Setiap pasien juga memiliki respon yang berbeda terhadap antipsikotik yang dikonsumsi. Beberapa menunjukkan respon yang baik dan cepat mengalami remisi, namun beberapa memiliki respon kesembuhan yang lambat. Pada penelitian ini, banyak pasien yang memiliki durasi rawat inap episode pertama lebih dari 30 hari. Hal-hal ini diduga sebagai salah satu faktor yang mempengaruhi durasi rawat inap episode pertama pada penelitian ini.

Adanya indikasi sosial juga diyakini sebagai 
faktor yang memperlama durasi rawat inap episode pertama. Banyak sampel pasien penelitian ini merupakan orang-orang dengan status terlantar dan dibawah perlindungan Dinas Sosial. Tidak adanya informasi mengenai alamat tempat tinggal dan keluarga menyebabkan pasien-pasien tersebut harus tetap dirawat di RSJ meskipun indikasi rawat inap sudah tidak ada lagi. Penelitian ini juga tidak menemukan adanya pencatatan indikator-indikator untuk mengukur keparahan dan remisi gejala. Hal ini mempersulit peneliti untuk menentukan pasien yang masih ada indikasi rawat inap atau hanya tinggal sementara hingga dijemput oleh keluarganya. Halhal ini dapat menyebabkan hasil penelitian menjadi tidak bermakna secara statistik.

Penelitian yang dilakukan oleh Goodwin, memperlihatkan aktivitas inhibitor terhadap Toxoplasma terdapat pada fluphenazine, trifluoperazin, dan thioridazine. Dalam penelitian tersebut, aktivitas tersebut justru tidak dijumpai pada haloperidol dan clozapin. Didalam teori perkembangan mengenai skizofrenia, dopamin memegang peranan penting. Dopamin bertanggung jawab dalam menimbulkan gejala positif pada skizofrenia seperti halusinasi dan waham. Pada orang yang terinfeksi toksoplasmosis tampak gen tyrosin hydroxilase diekspresikan pada jaringan otak sehingga menyebabkan produksi berlebih dari dopamin. Sampai saat ini, masih belum dimengerti apakah gejala positif skizofrenia diinduksi oleh aktivitas Toxoplasma atau efek dari infeksi pada otak yang menahun. ${ }^{15,17}$

Pada penelitian ini, banyak dari sampel yang mendapatkan antipsikotik jenis haloperidol. Menurut penelitian Goodwin, obat tersebut tidak memiliki aktivitas inhibitor terhadap Toxoplasma. ${ }^{15} \mathrm{Hal}$ ini diasumsikan bahwa produksi dopamin tidak sepenuhnya dapat dikendalikan oleh haloperidol karena adanya komorbiditas dengan infeksi toksoplasmosis. Keparahan gejala, durasi rawat inap dan frekuensi berulang akan meningkat. Namun pada penelitian ini, hal tersebut tidak terpengaruh $(\mathrm{p}>0,05)$. Pada penelitian ini, justru banyak ditemukan pasien hanya mengalami satu kali rawatan inap selama setahun pertama perjalanan penyakitnya. Banyak faktor-faktor lain yang perlu diperhatikan seperti kepatuhan minum obat, kontrol rutin dan indikasi sosial rawat inap. Kepatuhan minum obat dan kontrol rutin termasuk faktor yang mendukung keberhasilan terapi dan menurunkan frekuensi kekambuhan.

Hubungan antara toksoplasmosis dengan skizofrenia tidak sesederhana itu. Penyebab skizofrenia tidak hanya oleh satu faktor saja. Banyak hal lain yang meliputi seperti kerentanan genetik dan faktor lingkungan. Toxoplasma lebih memungkinkan sebagai faktor yang mempengaruhi perjalanan penyakit skizofrenia dan meningkatkan keparahan gejalanya.

\section{KESIMPULAN}

Pada penelitian ini tidak ada pengaruh IgG anti Toxoplasma terhadap durasi rawatan skizofrenia episode pertama dan juga terhadap frekuensi rawat inap skizofrenia dalam setahun pertama perjalanan penyakitnya.

\section{DAFTAR PUSTAKA}

1. Holub D, Flegr J, Dragomirecka E, Rodriguez M, Preiss M, Novak T, Cermak J, Horacek J, Kodym P, Libiger J, Hoschl C, Motlova LB. Differences in onset of disease and severity of psychopathology between toxoplasma-sis-related and toxoplasmosis-unrelated schizophrenia. Acta Psychiatr. Scand. 2013; 127: 227-238.

2. Amir N. Skizofrenia dalam Buku Ajar Psikiatri. Badan Penerbit FKUI, Jakarta. 2010. Hal 170.

3. Sadock BJ, Sadock VA. Schizophrenia. In: Kaplan \& Sadock's: Sinopsis of Psychiatry. 10th ed. Philadelphia: Lippincott Williams \& Wilkins; 2007. p. 476.

4. Tamminga CA. Schizophrenia and Other Psychotic Disorders. In: Sadock BJ, Sadock VA, editors. Kaplan \& Sadock's: Comprehensive textbook of psychiatry. Vol 1. 9th ed. Philadelphia: Lippincott Williams \& Wilkins; 2009. p. 14321437.

5. Fekadu A, Shibre T, Cleare AJ. Toxoplasmosis as a cause for behavior disorders - overview of evidence and mechanisms. Folia Parasitol. 2010; 57: 105-113. 
6. Flegr, J. Influence of latent toxoplasmosis on the phenotype of intermediate hosts. Folia Parasitol. 2010: 57: 81-87.

7. Retmanasari A, Widartono BS, Wijayanti MA, Artama WT. Prevalence and risk factors for toxoplasmosis in Middle Java, Indonesia. Ecohealth. 2017 Mar 1; 14(1): 162-70

8. Khademvatan S, Saki J, Khajeddin N, IzadiMazidi M, Beladi R, Shafiee B et al. Toxoplasma gondii exposure and the risk of schizophrenia. Jundishapur J Microbiol. 2014; 7(11) : e12776.

9. Daryani A, Sharif M, Hosseini SH, Karimi SA, Gholami S. Serological survey of Toxoplasma gondii in schizophrenia patients referred to Psychiatric Hospital, Sari City, Iran. Tropical Biomedicine. 2010; 27(3): 476-482.

10.Horacek J, Flegr J, Tintera J, Verebova K, Spaniel F, Novak T, Brunovsky M, Bubenikova-Valesova V, Holub D, Palenicek T, Hoschl C. Latent toxoplasmosis reduces gray matter density in schizophrenia but not in controls: voxel-basedmorphometry (VBM) study. World J. Biol. Psychiatry. 2012; 13: 501-509.

11.Esshili A, Thabet S, Jemli A, Trifa F, Mechri A, Zaafrane F. Toxoplasma gondii infection in schizophrenia and associated clinical features. Elsevier. 2016;245:327-32. https://doi. org/10.1016/j.psychres.2016.08.056

12.Hamdani N, Daban-Huard C, Lajnef M, Richard JR, Delavest M, Godin O, et al. Relationship between Toxoplasma gondii infection and bipolar disorder in a French sample. J Affect Disord. 2013;148:444-8. http://dx.doi.org/10.1016/j. jad.2012.11.034

13.Celik T, Kartalci S, Aytas O, Akarsu GA, Gozukara H, Unal S. Association between latent toxoplasmosis and clinical course of schizophrenia - continues course of the disease is characteristic for Toxoplasma gondii infected patients. Folia Parasitol. 2015; 62: 015.

14.Celik T, Kaplan Y, Atas E, Oztuna D, Berilgen S. Toxocara seroprevalence in patients with idiophatic Parkinson's disease: chance, association or coincidence? Biomed. Res. Int. 2013; 685196.

15. Goodwin DG, Strobl JS, Lindsay DS. Evaluation of five anti schizophrenic agents against Toxoplasma gondii in human cell cultures. J. Parasitol. 2011; 97: 148-151.

16.Flegr J. Schizophrenia and Toxoplasma gondii: an undervalued association?. Expert Review of Anti-Infective Therapy. 2015;13(7):817-20. https://doi.org/10.1586/14787210.2015.105103 $\underline{3}$

17.Flegr J, Prandota J, Sovickova M, Israili ZH. Toxoplasmosis - A global threat. Correlation of latent toxoplasmosis with specific disease burden in a set of 88 countries. PLoS One. 2014;9(3):e90203. https://doi.org/10.1371/ journal.pone. 0090203 